\title{
Analysis of Financial Policy at Apple Company in 2020 Wang Kangyi ${ }^{1}$
}

\author{
${ }^{I}$ NFLSXC-+, Nanjing, China, 210000 \\ Author's Email:2369745948@qq.com
}

\begin{abstract}
Apple's 2020 Financial Report Apple today announced its 2020 second fiscal quarter financial report. Under the influence of the epidemic, total revenue was 58.3 billion U.S. dollars and net profit was 11.2 billion U.S. dollars. In the same period last year, revenue was US $\$ 58$ billion and net profit was US $\$ 11.6$ billion. This topic is based on the relevant data released by Apple Inc. and the financial statements of Apple Inc. in 2020.
\end{abstract}

Keywords: Apple Inc, Financial statements, Financial Policy

\section{INTRODUCTION}

In terms of products, iPhone revenue was 28.962 billion U.S. dollars, accounting for $50 \%$ of total revenue, compared with 31.51 billion U.S. dollars in the same period last year. Revenue from iPad was 4.368 billion U.S. dollars, accounting for $7 \%$ of total revenue, compared with 4.872 billion U.S. dollars in the same period last year. Revenue from Mac was US\$5.351 billion, accounting for $9 \%$ of total revenue, compared to US $\$ 5.513$ billion in the same period last year. Revenue from wearable devices, home equipment and accessories was US\$6.284 billion, accounting for $11 \%$ of total revenue, compared to US\$5.129 billion in the same period last year. Revenue from services was 13.348 billion U.S. dollars, accounting for $23 \%$ of total revenue, compared with 11.450 billion U.S. dollars in the same period last year. When Jobs was still alive, he said that Apple cannot live on the iPhone alone. Looking at it now, when all products are experiencing a decline in revenue due to the epidemic, Apple's Service products bucked the trend, with sales reaching 13.348 billion U.S. dollars, an increase of $17 \%$ from 11.450 billion U.S. dollars in the same period last year[1].

Apple's services include iTunes, App Store, Mac App Store, Apple Music, Apple Pay, AppleCare, Apple TV +, Apple News +, Apple Arcade, etc. Apple TV+ and Apple Arcade, which had been laid by Apple for many years, were released last year. They formally entered the film and television streaming and game subscription industries. At that time, there were still quite a few media questioning Apple's capabilities. Services such as TV+ and Apple Arcade have soared, and Apple's revenue has soared. After the release of the results for the second fiscal quarter of fiscal year 2020, Apple CEO Tim Cook said: "Although the new crown virus has had an unprecedented impact on a global scale, we are proud to report that in the service Driven by the quarterly record set by wearable devices, Apple has achieved growth in this quarter. In the current difficult environment, users are relying on Apple's products in new ways to stay in touch, get news, and stay creative. Strength and productivity. We feel inspired and encouraged not only to continue to meet these needs in innovative ways, but also to continue to give back to support the global response, from sending out tens of millions of masks and custom masks to medical professionals around the world, to Donate millions of dollars to organizations such as global citizens and the U.S. Food Fund." Apple's Chief Financial Officer Luca Maestri said: "We are proud of Apple's teams around the world, and We are proud of the resilience of our business and financial performance in this challenging period. Our active equipment installation base has reached the highest level in history in all regional markets and all major product categories. We have also returned this quarter. Created an operating cash flow of 13.3 billion U.S. dollars, an increase of 2.2 billion U.S. dollars over the same period last year.

\section{HISTORY OF APPLE}

Apple Inc. (NASDAQ: AAPL; formerly Apple Computer, Inc.) is an American multinational corporation that designs and markets consumer electronics, computer software, and personal computers. The company's bestknown hardware products include the Macintosh line of computers, the iPod, the iPhone and the iPad. Apple software includes the Mac OS X operating system; the 
iTunes media browser; the iLife suite of multimedia and creativity software; the iWork suite of productivity software; Aperture, a professional photography package; Final Cut Studio, a suite of professional audio and filmindustry software products; Logic Studio, a suite of music production tools; the Safari web browser; and iOS, a mobile operating system. As of July 2011, the company operates 357 retail stores in ten countries, and an online store where hardware and software products are sold. As of September 2011, Apple is the largest publicly traded company in the world by market capitalization and the largest technology company in the world by revenue and profit.

Established on April 1, 1976 in Cupertino, California, and incorporated January 3, 1977, the company was previously named Apple Computer, Inc., for its first 30 years, but removed the word "Computer" on January 9, 2007 , to reflect the company's ongoing expansion into the consumer electronics market in addition to its traditional focus on personal computers. As of September 2010, Apple had 46,600 full time employees and 2,800 temporary full time employees worldwide and had worldwide annual sales of $\$ 65.23$ billion.

For reasons as various as its philosophy of comprehensive aesthetic design to its distinctive advertising campaigns, Apple has established a unique reputation in the consumer electronics industry. This includes a customer base that is devoted to the company and its brand, particularly in the United States. Fortune magazine named Apple the most admired company in the United States in 2008, and in the world in 2008, 2009, and 2010. The company has however received widespread criticism for its contractors' labor, environmental, and business practices.

It is said that Apple's mobile phones are"launched every year, released every year, and released on sale." On the evening of November 6 , the two largest and smallest models of the iphone12 series, Pro Max and Mini, opened for pre-sale, and the result was a second time across the network. The innate advantage of the industry leader is that as an elephant in the house, no one can ignore his every move. On October 30th, Apple released its fullyear earnings report for 2020 .

Let me start with the conclusion. Before the Trump tax reform, the US corporate income tax was very high (35\%), and the global profits of multinational companies were taxed. Therefore, a large number of multinational companies choose to keep their funds outside the United States and invest again to avoid taxation. The same goes for Apple, which is why Apple has a large number of long-term investment securities on its books 2020 Financial Report Analysis.

\section{BUSINESS AND GROWTH}

The company's business growth has basically stagnated in the past two years, with revenue and net profit fluctuating in single digits. In 2020, the company's revenue was 274.515 billion U.S. dollars, an increase of $5.51 \%$ over last year, and its net profit was 57.411 billion U.S. dollars, an increase of $3.9 \%$ year-onyear.

It can be seen from the composition of the main business that the iPhone is still Apple's largest business, but its importance is not as good as before. In 2020, it has dropped by $12.5 \%$ from 2018. Perhaps this has something to do with the delayed release of iPhone 12 this year, But it will not affect the overall trend[2].

The proportions of other hardware businesses are gradually increasing. Among them, the wearables, home equipment and accessories sectors have surpassed Macs and iPads to become the third largest business sector.

It is worth paying attention to the service business, including advertising, Applecare, digital content, iCloud and other businesses. As far as my own usage is concerned, the money used to buy iCloud storage space is increasing every year. The photos plus the system backup of mobile phones and iPads exceed 100G, but it is still not enough. As time accumulates, Apple users will become more and more dependent on iCloud, because the experience of restoring data from backups on new phones is so good, and everyone who has used it knows that it's like a seamless injection of their souls. This prevents old users (such as me) from migrating to other mobile phone brands to a certain extent. The overall gross profit margin of the service business is $66 \%$, which is significantly higher than the $31.4 \%$ of the hardware business.

\section{OPERATING STATUS}

From the figure, we can intuitively see that the company's ROE has soared with the increase in the leverage ratio. The $87 \%$ + figure in fiscal year 2020 is very eye-catching, making people unable to look directly at it. In particular, the leverage ratio of nearly 5 times is close to the level of the financial industry. It is hard to imagine that this is a technology manufacturing company.

As we mentioned earlier, the company has a large number of long-term liabilities on its books, and it is these interest-bearing liabilities that accelerate the company's internal and external cycles. If we remove the impact of these interest-bearing liabilities, we can restore Apple's true profitability. After adjustments, the company's ROE in the past three years was $26.86 \%, 27.83 \%$, and $32.29 \%$, respectively. I think this is more in line with Apple's temperament[4]. 
The adjustment method is: adjusted $\mathrm{ROE}=$ net profit / (interest-bearing liabilities + shareholders' equity)

After mastering the company's true profitability, management borrow much money. The cost part was originally the focus of the financial report, looking at where the management spent the money. But Apple doesn't seem to want to disclose too much. It simply lists these pieces in the income statement, and it does not break them apart in the notes to the financial report.

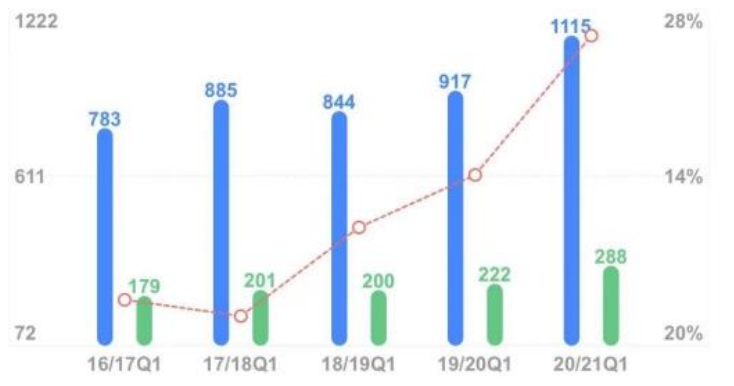

Figure 1. Income appropriation statement

The debt-to-asset ratio is $79.83 \%$, which is very high; The current ratio is $136.36 \%$ Interest-bearing liabilities accounted for $33.2 \%$ of total assets and have been increasing year by year since 2013. Apple has always had a large number of long-term securities assets on its books (it reached 194.7 billion in 2017 and then began to decline rapidly), and there will be 100 billion left in 2020[5].

Nevertheless, fluctuations in the value of securities are still a potential risk for Apple. In particular, due to the global economic downturn under the influence of the epidemic, if these assets are placed outside the United States as previously speculated, they will also be affected by the economy of the host country. From the content point of view, Apple invests mainly in corporate investment-grade bonds, treasury bonds and government bonds. The weighted average interest rate of long-term and short-term securities is $2.19 \%$. In the report for the last 10 years, the company has increased its long-term liabilities since 2013. After years of accumulation, it has reached a scale of 98.67 billion. Based on the company's hardware product operating cost of 151.2 billion, it means that inventory turnover is nearly 40 times a year.

In terms of cash flow, the company's operating cash flow has remained basically stable. In the past three years, stock repurchases have been large-scale. Fundraising cash outflows have mainly been repurchases and debt repayment. The funds obtained by issuing bonds each year are basically the same as those requiring for debt repayment.

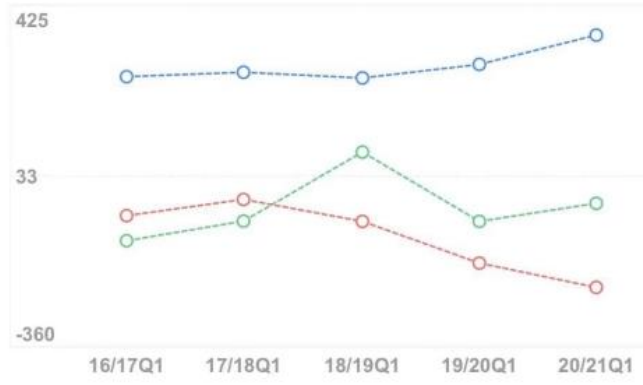

Figure 2. Cash flow statement

\section{U.S. TAX REFORM AND APPLE'S DEBT}

The part of the financial report is roughly like this. Let's briefly talk about the tax reform in the United States and Apple's high debt problem.

Before looking at the financial reports of other US stock companies, I didn't have that much interest in tax reform. Until this time Apple prompted me to take a closer look. The United States was really unfriendly to the income tax of multinational companies before the tax reform. Before Trump introduced the tax reform, the rate was $35 \%$, and the company's global profits are taxed, but the country's corporate income tax is allowed to be deducted.

For example, Apple made 100 yuan in a low-tax country. Assuming that the country's corporate income tax is 5\%, then Apple has 95 yuan left after paying the local tax. At this time, if Apple wants to take the 95 yuan back to the United States, it will need to pay a tax of $35 \%-5 \%=30 \%$, and only 65 yuan will be returned to the US account. But if Apple spends 95 yuan on long-term investments outside of the United States, it won't have to pay this tax.

In other words, the cost for Apple to use overseas funds to return to China is $30 \%$ (the $5 \%$ part assumed above is a fixed cost). If Apple chooses not to use overseas funds, but instead borrows 100 yuan (assuming interest rate 3\%), then actual funds held are 195 yuan, but the cost is only 3 yuan. Considering that some funds are invested in long-term securities with a return of $2.19 \%$, then the true capital cost is less than 3 yuan. In this way, keeping funds outside of the United States and borrowing domestically has become a more cost-effective financial arrangement.

In 2018, Trump's tax law reforms began to be implemented, reducing corporate income tax to $20 \%$, and levying taxes only based on territories, which gave multinational companies an incentive to move profits from outside the country back to the United States. In addition, the tax reform has also introduced a one-time "repatriation tax", which only imposes a one-time tax rate of $15 \%$ on current assets that return to the United States. This has stimulated a large wave of multinational companies to return funds in 2018. Tim Cook also 
promised that Apple's funds would return to the United States and increase investment in the United States.

It can be seen from Apple's financial report that since 2018, the scale of long-term investment securities on Apple's books has decreased significantly, and long-term liabilities have also shown a downward trend (there will be a rebound in 2020, and it is speculated that it is related to the impact of the epidemic). It is from 2018 that Apple has a large amount of its own funds and began to repurchase the company's stock in a large amount. In the past three years, Apple has grown from a market value of 900 billion to 2.02 trillion, an increase of more than $124 \%$.

\section{CONCLUSION}

Apple's performance is becoming more and more "soft", which also raises the overall gross profit margin of the company. In terms of regional markets, it is not difficult to see the changes are taking place. The most noteworthy of these is Greater China, where both revenue and share data are declining. This will reduce the number of outstanding shares in the market, increase the intrinsic value of existing stocks per share, and make a stock even more valuable, is bound to stimulate the stock price to rise.

\section{ACKNOWLEDGMENT}

Thanks to the teachers who helped me in the writing process. Thank them very much.

\section{REFERENCES}

[1] Apple Financial Results. 2021.

https://www.apple.com/investor/earnings-call/

[2] Apple Financial Data. Quarterly Earnings Reports.2021.

https://investor.apple.com/investor-relations/

[3] Apple Reports First Quarter Results.2021

https://www.apple.com.cn/newsroom/pdfs/FY2120 Q1\%20Consolidated\%20Financial\%20Statements. pdf

[4] Investor Updates. Second Quarter.2021

Results.https://investor.apple.com/investorrelations/

[5] Investor Updates. Second Quarter.2021

https://investor.apple.com/investor-relations/ 